\title{
Clause and Sentence Syntax
}

\subsection{Equational Sentences}

\subsubsection{Without Copula}

Equational sentences in Hasidic Hebrew, as in other varieties of the language, can be expressed by means of a subject immediately followed by its predicate, e.g.:

- אני גוטער יוד 'I am a Hasidic rebbe' (Gemen 1914:59)

- מדוע לא אמרתם שהחלב אסור 'Why didn't you say that the milk is forbidden?' (Moses Leib of Sasov 1903: 23b)

- הם מתים שעמדו מקבריהם 'They are corpses who have arisen from their graves' (Shenkel 1903b: 24)

- ועכשיו הם פשוט בעלי תאוות 'And now they are simply slaves to desire' (Munk 1898:17)

- ושמו ר' דוד ליב 'And his name was Reb David Leib' (Singer 19oob: 3)

\subsubsection{With Copula}

Although Hasidic Hebrew equational sentences may be expressed simply by means of a subject followed by a predicate, somewhat more commonly a copula serves to link the subject with the predicate. The copula is היא/הוא in the singular and הם/המה in the plural, as in the two sets of examples below respectively. The subject may be a noun or a pronoun, as the extracts illustrate.

\section{Singular}

- מאיזה עסק הוא פרנסתכם 'From which business is your livelihood?' (Bromberg 1899:25)

- הנה בעל האכסניא הלז הוא עשיר גדול 'You see, this innkeeper is very wealthy' (M. Walden 1912:62)

- האי הוא העולם הזה 'The island is this world' (Shenkel 1903b: 32 )

- והבין שהוא הוא האברך 'And he understood that he was the yeshivah student' (Gemen 1914: 68)

- אבל אנכי הוא אנכי ואינם מבלבלים אותי 'But I am me, and they don't confuse me' (Zak 1912: 23)

(C) LILY KAHN, 2015 | DOI: 10.1163/9789004281622_015

This is an open access article distributed under the terms of the Creative Commons 
- ואח"ז אמרתי תדעו שאני היא תלמיד רבינו הגדול 'And after that I said, "Know that I am a student of our great Rebbe"' (Kaidaner 1875: 40a)

\section{Plural}

- גם הבהמות ועבדים והכלים המה משורש נשמתו The animals and servants and the vessels are also from the root of his spirit' (Rakats 1912, pt. 1:17)

- אלקיכם הם האלקים האדירים 'Your God is the great[est] God' (Bodek 1865c: 8)

- ואמר שהוא עם פועליו הם רק שמנה המירים (And he said that he and his workers were only eight [men]' (Kaidaner 1875: 10a)

- אמר המן לזרש אני ואתה הם כמו מרדכי ואסתר 'Haman said to Zeresh, "You and I are like Mordecai and Esther"' (Sobelman 1909/10, pts. 1-2: 32)

The Hasidic Hebrew use of these pronouns as a copula most likely evolved under multiple influences. The same pronouns are found in seemingly similar contexts in Biblical and Rabbinic Hebrew (see Waltke and O'Connor 1990: 297; Pérez Fernández 1999: 19; Azar 2013c). However, there is some agreement that the biblical pronouns do not strictly speaking serve as copulas but rather play other roles, e.g. functioning as subjects following topicalized nouns (Waltke and O'Connor 1990: 131-132, 297-299; Muraoka 2013). With respect to Rabbinic Hebrew there is less consensus: for example, Kaddari (1991: 248-263, 268-269) argues that the pronouns are likewise not true copulas but rather serve other functions such as the highlighting of the subject; by contrast, Azar (2013d) supports the copular interpretation. Regardless of the true syntactic nature of the biblical and rabbinic constructions, it is likely that the Hasidic Hebrew use was influenced by their appearance in the canonical texts. Moreover, Kaddari (1991: 268-273) notes the existence of a copular use of pronouns in responsa literature (which he suggests evolved under the influence of vernacular languages), and the Hasidic Hebrew usage is likely to have been reinforced by its presence in these writings. Finally, the authors' proclivity for the use of a copula was perhaps reinforced by the existence of the verb 'to be' in their native Yiddish. Kaddari (1991: 269) suggests that the use of pronouns as copulas in Israeli Hebrew is rooted in the responsa literature, but it is possible that the Hasidic Hebrew usage contributed to its adoption as well. 


\subsection{Negation}

The Hasidic Hebrew authors employ four different negative particles, namely בל אין , , אל ,לא. As in other forms of Hebrew, each of these particles is employed in specific syntactic contexts, discussed in turn below.

\subsubsection{With}

\subsubsection{Qatal}

Hasidic Hebrew qațal is invariably negated by לא, as below. In this respect Hasidic Hebrew usage resembles the standard in earlier forms of the language dating back to Biblical Hebrew (see e.g. Williams 2007: 143).

- וגם עתה לא ענה לו מאומה 'And also now he did not answer him anything' (Rodkinsohn 1865:12)

- עדיין לא התפללתי 'I haven't prayed yet' (Chikernik 1902:14)

- אני לא פעלתי מאומה 'I didn't do anything' (Singer 190ob:1)

- אנכי לא ידעתי ולא הכרתי את הרב המגיד 'I didn't know and wasn't familiar with the Maggid' (Seuss 1890:10)

\subsubsection{Yiqțol}

Indicative yiqtol, like qațal, is consistently negated by לא in Hasidic Hebrew, as below. Again, this corresponds to the standard established by Biblical Hebrew (see e.g. Williams 2007: 143).

- לא אספר לכם ולא אגיד לכם מאומה 'I won't tell you and I won't say anything to you' (Chikernik 1908: 10-11)

- נאכל ונשתה ולא נמהר 'We'll eat and drink and we won't hurry' (Rodkinsohn 1865:12)

- הלא בזה לא ישתלם לך החוב 'Indeed the debt will not be paid for you with this' (Ehrmann 1903: 21b)

- לא אוכל עוד להציל את בנך 'I will not be able to save your son again' (Bodek? 1866: 2b)

While yiqtol denoting negative commands is typically negated by אל (see 14.2.2), it is occasionally negated by לא, as below.

- הגד האמת לא תכחד 'Tell the truth; don't deny' (Rodkinsohn 1865:2)

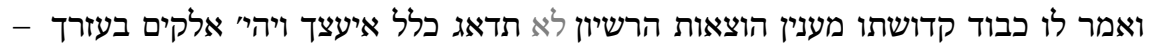
'And His Holy Honour said to him regarding the matter of getting the permit, "Don't worry at all; I will advise you, and God will assist you"' (Kaidaner 1875: 41a) 
- כי יפגשך איש לא תדבר 'When someone meets you, don't speak' (Michelsohn 1910a: 57 )

- לא תדאג מסתמא יעזור השי"ת 'Don’t worry, the Holy One blessed be He will surely help' (Chikernik 1902: 29)

- לא תבקש ממנו הסוס הנ"ל כי הוא יקר בעיני 'Don't ask for that horse from him, because he is precious in my eyes' (A. Walden 186o?: 17b)

Significantly, the Hasidic Hebrew authors seem to treat the two negative particles interchangeably; although אל is employed more frequently than לא in negative command contexts, there does not seem to be any semantic or syntactic difference motivating the selection of one particle instead of the other on any occasion, with both employed e.g. in direct, immediate commands issued to a specific addressee. This contrasts with the Biblical Hebrew standard pattern whereby is typically employed in immediate or urgent contexts whereas is used in strong or durative, often legislative, settings (see Waltke and O'Connor 1990: 567; Gibson 1994: 81; Joüon-Muraoka 2006: 343, 348). Similarly, it differs from Rabbinic Hebrew, in which direct negative commands are regularly constructed with אל (Pérez Fernández 1999: 124).

\subsubsection{Qotel}

The Hasidic Hebrew qotel is typically negated by (see 14.2.3), but is negated by on very rare occasions, e.g.:

- לך נא לחוץ ושמע אם לא משמיעים הפעמונים קול רעש Please go outside and listen whether the bells are making a sound' (Rodkinsohn 1864b:16)

This convention does not derive from Biblical Hebrew, in which the qotel is almost always negated by (van der Merwe, Naudé, and Kroeze 1999: 318), with employed on only three occasions (Zephaniah 3:5, Job 12:3, and Job 13:2). Rather, it more closely resembles Rabbinic Hebrew, in which the qotel may be negated by לאין in addition to the more frequent. However, here too the two corpora differ as in Rabbinic Hebrew the selection of לא with a qotel typically serves to indicate that the negated element contrasts with a preceding clause (Sharvit 2004: 71-72), while in Hasidic Hebrew no such meaning is apparent. Conversely, the same phenomenon is attested somewhat sporadically in responsa literature from the sixteenth century onwards, becoming the norm in the twentieth century (Betzer 2001: 92). As in many other cases discussed throughout this volume, the Hasidic Hebrew convention may be rooted in this earlier practice. The Hasidic Hebrew usage is more widespread than that of the earlier responsa, and yet is not standard as in the twentieth-century ones, 
suggesting that the overall trend in Eastern European forms of Hebrew towards use of ל to negate qotel began as a marginal feature and then developed into a progressively more widespread one over the course of the next few centuries.

\subsubsection{Non-Verbal Sentences}

Hasidic Hebrew negative existential sentences are typically formed with the particle אין 'there isn't/aren't'. However, they may occasionally be formed with ל, e.g.:

- אנחנו לא רחוקים ממעזבוש 'We are not far from Medzhybizh' (Munk 1898: 21)

- והכל הכירו בו שהוא לא איש עני פשוט 'And everyone recognized in him that he was not a simple poor man' (Heilmann 1902:107)

- אבל אנחנו לא כן 'But we are not like that' (Sobelman 1909/10, pts. 1-2: 32)

Moreover, on extremely rare occasions the existential particle שיש 'there is/are' is attested in conjunction with the negator לא, as below:

- בכל העיר לא יש דגים 'There is no fish in the whole city' (Rodkinsohn 1865: 28)

- ולא יש בו תועלת דג' 'And he has no use' (Seuss 1890: 46)

This practice is attested in Biblical and Rabbinic Hebrew but is quite a marginal feature: it appears once in Biblical Hebrew (in Job 9:33) and several times in rabbinic literature, in the Tosefta, the Palestinian Talmud, and Deuteronomy Rabba. By contrast, it is attested much more commonly in medieval and early modern Hebrew literature, e.g. in the commentaries of Abarbanel and Alshich. It is also found in responsa literature (Betzer 2001: 92). It is therefore possible that the Hasidic Hebrew use of the construction, as in the case of many other phenomena discussed in this volume, was inspired by its more frequent appearance in these sources. However, the Hasidic Hebrew authors' use of this construction is extremely negligible and so they cannot be said to have been strongly influenced by any such earlier writings in this respect.

\section{אל אי אי אי}

The particle אל מn Hasidic Hebrew is the standard negator for second and third person yiqtol with command force, as shown below.

\section{Second Person}

- ויען לו הרב אל תפחד 'And the rabbi answered him, "Don't be afraid"' (Rodkinsohn 1864b: 8) 
- אל אל תמש 'Don't deny' (Bodek 1865a: 71)

- אל נא תמלא שחוק פיך 'Don't fill your mouth with laughter' (? 1894:6)

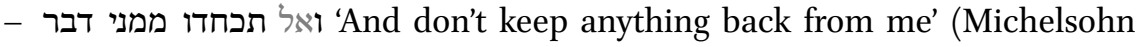
1910a: 41)

\section{Third Person}

- אל ידאג 'Let him not worry' (Ehrmann 1903: 47b)

- אל יבזבז 'Let him not waste' (Rakats 1912, pt. 1:3)

- אל יאמר מפורש 'Let him not say it outright' (J. Duner 1899:14)

- אל ישים אשם עלינו 'Let him not lay blame on us' (Rodkinsohn 1864b: 40)

- ואיש אל ילך אחרינו 'And let no man go after us' (Landau 1892: 17)

This usage corresponds in great measure to both the biblical and rabbinic models. However, it is closer to Rabbinic Hebrew in that both forms of the language employ the particle as the standard negator of yiqtol with a command sense (see Pérez Fernández 1999: 124), whereas Biblical Hebrew regularly uses לא in durative command contexts (Waltke and O'Connor 1990: 510); ${ }^{1}$ moreover, Biblical Hebrew employs the jussive in negative commands when such forms exist (Waltke and O'Connor 1990: 571), whereas Hasidic Hebrew uses only the yiqtol.

\subsubsection{With}

\subsubsection{Equational Sentences}

Hasidic Hebrew non-verbal equational sentences are typically negated by the particle אין The predicates in such sentences are varied; they may consist of common and proper nouns, adjectives, qatuls, etc. The subject may be a noun in conjunction with unsuffixed אי noun or pronoun in conjunction with suffixed איץ, as in the second set.

\section{Unsuffixed}

- אין זה קייסר פאוויל 'This is not Emperor Pawel' (Rodkinsohn 1864b: 16)

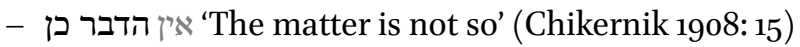

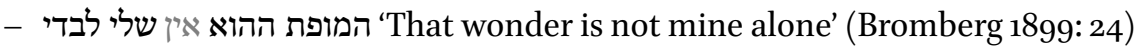

- הנה אבא אין צריך לאמירת קדיש שלי לביר 'Look, father does not need me to say kaddish' (Landau 1892: 34)

1 Hasidic Hebrew uses לא in negative command contexts as well, but treats it as interchangeable with (though less frequent than) אל; see 14.2.1.2. 


\section{With Suffix}

- אנכי אינני דאקטער 'I'm not a doctor' (A. Walden 186o?: 26b)

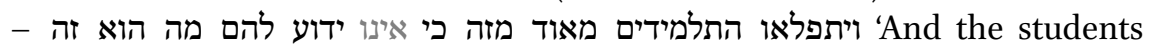
wondered greatly at this, because it was not known to them what it was' (Kaidaner 1875: 15a)

- זה הילד אינו שלה 'This child is not hers' (Teomim Fraenkel 1911a: 75)

- אינכם צריכים לבוא אלי אילד 'You don't have to come to me' (Michelsohn 1912: 31)

\subsubsection{Qoțel}

Qotel is typically negated by אין. The subject in such cases is usually an independent pronoun, as in the following examples. The negative particle most commonly precedes the subject, though it may occasionally follow it, as in the final example. These variations in word order do not seem to have clear semantic significance, though in some cases fronting the subject may serve to draw attention to it.

- אין אנחנו פוסקים מזוהר 'We don't make legal rulings based on the Zohar' (Rodkinsohn 1864b: 27-28)

- אין אתם מחויבים לילך אצלו 'You aren't obliged to go along with him' (J. Duner 1899:85)

- ואין אני יודע כלום 'And I don't know anything' (Rakats 1912, pt. 1:56)

- ואין אני רואה היכן ללכת יכודי כ'And I don't see where to go' (Chikernik 1903a: 16)

- ואני אין לומד כ"ב 'And I do not study so much' (Bromberg 1899: 9)

In most cases when the negative particle appears in conjunction with a pronominal subject, the particle is unsuffixed and the pronominal subject is expressed independently, as above. However, in some cases the pronominal subject is expressed by means of a suffix, e.g.:

- אינני עוסק בחילוקים 'I don't get involved in disputes' (Rodkinsohn 1864b: 28)

- איני רוצה לילך ב 'I don't want to go' (Ehrmann 1911: 43a)

In such cases the suffixed particle may additionally appear in conjunction with an independent pronoun, as below. The authors' motivation for employing both a suffixed particle and an independent pronoun are not always obvious since the pronoun is not needed for clarity. In some such cases the pronoun may have been added in order to draw heightened awareness to the subject, but in most instances the two constructions are used interchangeably. Comparison of the last example above with the last example below illustrates this, as both 
contain a similar collocation but the former lacks an independent pronoun while the latter contains one.

- ואני איני יכול להושיעך 'And I can't save you' (Breitstein 1914:38)

- הלא אתה אינו שוטה 'Of course, you're not a fool' (Munk 1898: 65)

- אמר הוא לאשתו כי הוא אינו הולך אף פסיעה אחד 'He said to his wife that he wouldn't go even one step' (Ehrmann 1905: 48b)

- אני איני רוצה לצאת 'I don't want to go out' (Zak 1912:19)

אין appears in conjunction with a nominal subject only rarely in sentences with a qoțel, e.g.:

- לכן אין ישראל רואהו 'Therefore Jews do not see it' (Moses Leib of Sasov 1903: $23 b$ )

14.2.3.3 Qațal

Very rarely the negator אין appears in conjunction with a qațal, as below.

- אין אני אליהו ואין אני באתי לקחת את העשירות שלכם ח"ו 'I am not Elijah, and I have not come to take your wealth, God forbid' (Munk 1898: 35)

- ואין שום איש ראה בלקחו כל זאת 'And no-one saw when he took it' (Sofer 1904:6)

This type of non-standard usage does not seem to be rooted in Biblical or Rabbinic Hebrew, in which אין does not appear in conjunction with the qatal (see e.g. van der Merwe, Naudé, and Kroeze 1999: 320-321 and Williams 2007: 146-147 for the use of אין in Biblical Hebrew; see Segal 1927: 162-163 for its use in Rabbinic Hebrew). Likewise, it does not have clear precedent in medieval or early modern literature. The motivation for the Hasidic Hebrew authors' use of this non-standard construction is thus unclear, but given its extreme marginality it is best considered an anomaly.

\subsubsection{Yiqtol}

Just as the negator is occasionally attested in conjunction with a qatal, so it is very rarely used to negate a yiqtol, as below. As discussed above in the case of the qatal, this usage does not seem to have precedent in Biblical or Rabbinic Hebrew. Likewise as in the case of the qațal, it is best regarded as an occasional anomaly rather than an integral component of Hasidic Hebrew grammar.

- אמר החתן לאביו איני אלך אמר לו אביו ולמה "The groom said to his father, "I won't go." His father said to him, "And why?"' (Munk 1898: 36) 


\subsubsection{With בל(ל)}

Although negative commands are typically conveyed by the particle אל ליא, or more rarely לא, preceding the yiqtol (see 14.2.1.2 and 14.2.2), in rare cases the particle (ל) is used instead, as below.

- ובל תחשוב כי היא וחלומותיה היו פשוטים כדרך שאר נשים 'And do not think that she and her dreams were simple like other women' (Bromberg 1899:5)

- והאיש נ"ל הי' כל כך חלש אשר הרופאים הזהירו אותו לבל יתענה שום תענית 'And that man was so weak that the doctors warned him not to observe any fast' (Seuss 1890: 5)

- מוזהרים ועומדים אנחנו לבל יראו ולא ישמעו מאתנו מאומה (We are standing cautiously so that they don't see or hear anything from us' (Laufbahn 1914: 51)

- אז שלח השר הנ"ל איזה אדון מבערלין באזהרה לבל יגלה לשום אדם מה שצריך לו 'Then that minister sent a certain lord from Berlin with the warning that he should not reveal what he needed to anyone' (Munk 1898: 20)

This particle is a feature of various earlier forms of Hebrew, starting with the Hebrew Bible but also attested in rabbinic and medieval literature. The Hasidic Hebrew usage does not seem to be rooted directly in that of its biblical or rabbinic antecedents, given that the biblical particle is confined largely to poetry and is used only with the jussive and cohortative in this sense, not with the yiqtol (Williams 2007: 148), while in tannaitic writings it is restricted to biblical references (Pérez Fernández 1999: 174). By contrast, in medieval writings by e.g. Abarbanel, it can be used in conjunction with second person yiqtol in the same negative command sense, and therefore, as in many other elements of Hasidic Hebrew grammar, this medieval usage is likely to be the immediate inspiration for the authors' employment of this construction.

The authors do not seem to have had a clear semantic motivation for the occasional selection of this particle instead of the others. It is possible that it was chosen in order to add an element of extra weight to the prohibition, but this is not certain. It is possible that, as in many other cases in which the authors employed multiple variants with similar meaning, they regarded the various particles as interchangeable or alternated them for stylistic reasons.

\subsubsection{Negation of Infinitives}

Hasidic Hebrew infinitives absolute never appear in negative contexts.

Infinitives construct may be negated in several different ways. The existence of these alternative methods of negation is one of numerous examples seen throughout Hasidic Hebrew grammar whereby the authors employ biblical and post-biblical forms and constructions relatively interchangeably. 
Infinitives construct prefixed by 'not to', as below. This construction has a precise counterpart in Mishnaic Hebrew (Sharvit 1998: 337; Pérez Fernández 1999: 144).

- רבינו בקש אותנו שלא להניח אותך ליסע לביתך 'Our Rebbe asked us not to let you travel to your house' (Rodkinsohn 1865: 49)

- הרופא פקד עליו שלא לשתות 'The doctor had instructed him not to drink' (Michelsohn 1912:18)

- היה שולח לבית מדרשו שלא להמתין הצבור עליו 'He would send [word] to his prayer-house that the congregation should not wait for him' (Bromberg 1899: 32)

More rarely, infinitives construct may be negated by the biblical particle לבלתי 'not to', as below. When prefixed by - ל, as in the first two examples below, this is only one of several options for negation. Conversely, in the case of those not prefixed by לבלתי, לב is the only option for negation, as shown in the subsequent examples. This is to be expected given that לבלתיל is the standard way of negating unprefixed infinitives construct in Biblical Hebrew (Joüon-Muraoka 2006: 571; Williams 2007: 150).

- וכן אעשה לבלתי ללמוד אצל אליהו 'And I will do so, not to study with Elijah' (Laufbahn 1914: 50)

- עשיתי הדבר הזה לבלתי לבא אל בית הרב 'I did this thing, not to come to the Rebbe's house' (Shenkel 1903b: 17)

- וגם נתן צו לבלתי שרוף את ספריו 'And he also gave an order not to burn his books' (Jacob Isaac ben Asher of Przysucha 1908: 96)

- מה שהבטחתן אותי, לבלתי תת להלשין עלי (What you promised me, not to let [anyone] report me' (Breitstein 1914: 38)

Somewhat more rarely, they may be negated by the particles לבלי or לבל , as below. Again, the infinitive construct may be prefixed by -ל, as in the first two examples, or unprefixed, as in the final one.

- ואני אומר לך לבל להתאמץ בתפלה עבור זה 'And I am telling you not to make too much effort in prayer for this' (Bromberg 1899:4)

- וביום השני בא פקודה אחרת לבלי לתלות אותם ח"ו 'And on the next day a different order came not to hang them, God forbid' (Munk 1898: 22)

- ותקבל על עצמך לבלי עשות יותר כדברי' אלה 'And you will take it upon yourself not to act according to these words any more' (Ehrmann 1903: 1b) 
Interestingly, these two constructions do not seem to be based on clear historical precedent. They do not appear to be attested in tannaitic or Talmudic literature; neither do they appear in the medieval writings that often inspired Hasidic Hebrew usages. However, they have a partial parallel in Alshich's biblical commentary, in which לבל sometimes appear before an unprefixed infinitive construct (e.g. לבלי תל 'not to give', Alshich on Numbers 32), and this construction may have formed the basis for the Hasidic Hebrew prefixed version.

\subsection{Constituent Order}

Hasidic Hebrew typically displays a mix of svo and vso constituent order. In addition, other more marked constituent orders sometimes appear in specific syntactic settings.

\subsubsection{SVO}

svo order is relatively common in independent verbal and equational clauses with nominal and pronominal subjects, as in the following sets of examples respectively. svo order in these types of clauses is attested in various earlier forms of Hebrew and therefore its appearance in the Hasidic Hebrew tales is not remarkable. However, there are some differences, e.g. svo clauses in Biblical Hebrew are typically regarded as marked (Moshavi 2013b).

\section{Verbal Clauses with Nominal Subjects}

- והתלמידים אמרו כי הם שמשהו בחייו (And the students said that they had served him in his life' (Rodkinsohn 1864b: 25)

- ויסע האיש הנ״ל לביתו ואשתו ילדה בן זכר 'And that man went home, and his wife bore a son' (Chikernik 1908:12)

- והרב פתח הקמיע 'And the rabbi opened the amulet' (Ehrmann 1903: 19b)

- האיש פייביש הלך להבעש"' 'The man Faivush went to the Ba’al Shem Tov' (Sofer 1904: 9)

\section{Verbal Clauses with Pronominal Subjects}

- פתאום אמר הבעש"ט אני רוצה לעשן לולקע 'Suddenly the Ba’al Shem Tov said, "I want to smoke a pipe"' (A. Walden 1860?: 14b)

- ואתה תלך מגולה לגולה 'And you will go from exile to exile' (Ehrmann 1903:39b)

- והוא המתין להם מלדי -And he waited for them' (J. Duner 1899:34) 
- And he started to hear a persistent rumour' (Shenkel 1903b: 19)

- 'And we passed by among them' (Heilmann 1902: 98)

\section{Equational Clauses with Nominal Subjects}

- מדוע לא אמרתם שהחלב אסור 'Why didn't you say that the milk is forbidden?' (Moses Leib of Sasov 1903: 23b)

- האשה גברת הבית הזאת הוא זונה 'The woman, the mistress of this house, is a whore' (Rodkinsohn 1865: 29)

- הילד הוא חכם 'The child is wise' (Zak 1912:163)

\section{Equational Clauses with Pronominal Subjects}

- ועתה המה מנכבדי העיר 'And now they were among the most respected of the city' (Bromberg 1899: 22)

- ועכשיו הם פשוט בעלי תאוות 'And now they are simply slaves to desire' (Munk 1898: 17)

- הוא נכדו של הבעש"ט זלל"ה 'He is the grandson of the Ba’al Shem Tov of eternal memory' (Zak 1912: 153)

svo order is also often found in subordinate clauses, e.g.:

- אמר לו רבינו שמע מה שמאיר אומר לך נסע לביתך 'Our rebbe said to him, "Listen to what Meir says to you; go home (lit: travel to your home)" (HaLevi 19og: 53)

- סוף דבר שהאיש הגבור ההוא שמח שמחה גדולה מאד 'The end of the matter was that that mighty man rejoiced greatly' (J. Duner 1899: 11)

- כי הוא איסור גדולי 'because it is a big prohibition' (Leichter 1901: 9a)

- כי כי אני כבר זקנתי 'because I have already grown old' (Zak 1912: 15)

- אך אני יודע בבירור שהבהמה היתה כשרה 'But I know with certainty that the beast was kosher' (M. Walden 1913, pt. 3:9)

\subsubsection{VSO}

vso order is extremely frequently attested in the same types of independent clauses as svo order, as shown below. These two constituent orders are interchangeable in pragmatic terms, but are not evenly distributed: both svo and vso are employed with similar frequency in verbal clauses, but in nonverbal clauses vso is much more common with pronominal subjects than with nominal subjects. The preference for vso in independent verbal clauses has 
precedent in both Biblical and Rabbinic Hebrew (Moshavi 2013b; Shivtiel 2013). Conversely, it differs from the authors' Yiddish vernacular, in which independent clauses are typically svo (Jacobs 2013: 223-224).

\section{Verbal Clauses with Nominal Subjects}

- התחיל האיש לבכות 'The man began to cry' (HaLevi 1909: 54)

- עברו שעות אחדות 'Several hours passed' (Berger 1910a: 25)

- והכה הבעש"ט להצדיק מכות אכזריות 'And the Ba’al Shem Tov struck the righteous man [with] brutal blows' (Kaidaner 1875: 22a)

- ונתרשל אותו אדם לעשות כן 'And that man neglected to do so' (J. Duner 1899:68)

- אמר החתן לחביריו שהכלה יש לה פנים כמו נכרית 'The groom said to his friends that the bride had a face like a non-Jewish girl' (Michelsohn 1905: 65)

\section{Verbal Clauses with Pronominal Subjects}

- אמר הוא לאשתו כי הוא אינו הולך אף פסיעה אחד 'He said to his wife that he wouldn't go even one step' (Ehrmann 1905: 48b)

- והשיב רוצה אנילעשות לכם איזה שימוש'And he replied, "I want to do some service for you"' (Lieberson 1913: 21)

- עדיין לא התפללתי ורוצה אני לילך להתפלל 'I haven’t prayed yet, and I want to go pray' (Chikernik 1902: 14)

- ונסע הוא ז״ל להה"ק מרוזין 'And he, of blessed memory, travelled to the holy Rebbe of Ruzhin' (Brandwein 1912: 33)

- 'And he got up on the second night' (Rakats 1912, pt. 1:8)

\section{Equational Clauses with Nominal Subjects}

- טוב הדבר 'The matter is good' (Zak 1912:152)

\section{Equational Clauses with Pronominal Subjects}

- הנני רואה כי איש עני אתה 'I see that you are a poor man' (Ehrmann 1905:53b)

- איש ישר הוא -He is an upright man' (Rodkinsohn 1865:1)

- הנה ירא אנכי מפני השוטרים 'You see, I'm afraid of the officers' (Seuss 1890:10)

- וקילס אותו מרן מאוד כי טוב הוא 'And our Rebbe praised him greatly, because he is good' (Landau 1892: 13)

Moreover, main clauses preceded by an adverb, prepositional phrase, or subordinate clause are almost always vso, as shown below. This may be attributable 
to influence from Yiddish, in which an identical phenomenon is found (Katz 1987: 229-236); such influence was most likely reinforced by the widespread appearance of vso order in this and other contexts in earlier forms of Hebrew.

\section{Following Adverb}

- ושם שכר הרב דירה 'And there the Rebbe rented accommodation' (Rodkinsohn 1864b: 38 )

- אולי מכיר אתה את האברך 'Maybe you know the yeshivah student' (Bromberg 1899: 15)

- עתה מוכרח אני לנסוע לאונגרין (Now I must travel to Hungary' (Berger 1907:47)

- אז פתח הרב הקדוש את פיו לארו -Then the holy Rebbe opened his mouth' (N. Duner 1912:34)

- פעם בא דיבוק להרב הקדוש 'Once a dybbuk came to the holy Rebbe' (Gemen 1914:69)

- אח"כ שכבו התלמידים לישן 'Afterwards the students lay down to sleep' (Heilmann 1902: 9)

- פ"א באה אשה אחת אל הרבי 'Once a woman came to the Rebbe' (Menahem Mendel of Kamelhar 1908: 22)

- אז הבינה אמו הצדיקת 'Then his righteous mother understood' (Teomim Fraenkel 1910:44)

\section{Following Prepositional Phrase}

- אחר הצהריים באו הפריצים לשחק מן היהודי 'In the afternoon the landowners came to laugh at the Jew' (Ehrmann 1903: 24b)

- 'In the night a man came' (Jacob Isaac ben Asher of Przysucha 1908:52)

- אחר הסעודה הלכו כל אנשים הקרואים לביתם After the feast all of the guests (lit: invited/called men) went home' (Sofer 1904: 1)

- ובדרך נהפכה המרכבה 'And on the road the carriage turned over' (Brandwein 1912:38)

- ואח"ז נסעו שני הצדיקים לדרכם (And after that the two righteous men went on their way' (Hirsch 1900: 20)

- The next day that man came to the Rebbe's house' (Michelsohn 1910c: 68)

- בחורף שנת תרנ"ג פסקה פרנסתי 'In the winter of 1893 my earnings stopped' (Yellin 1913:38)

- ולמחרת בבוקר השכים האיש הנ״ל בזריזות והלך להרבי 'And the next day in the morning that man quickly got up early and went to the Rebbe' (M. Walden 1912: 10) 


\section{Following Subordinate Clause}

- וכאשר בא זמן התפל' עמד הסוס מעצמו 'And when the time for prayer came, the horse stopped by itself' (Kaidaner 1875: 9a)

- ולאחר שחזר לביתו חזרו העננים והשלגים והגשמים 'And after he went back to his house the winds and snow and rains came back' (Landau 1892: 38 )

- ואחרי מותו מלך בנו הקיסר אלכסנדר 'And after his death his son, the Emperor Alexander, ruled' (Bodek 1865a: 30)

However, in contrast to Yiddish, in Hasidic Hebrew this practice is not universal: in rare cases svo order is attested, as below. This may indicate that, although the Hasidic Hebrew authors were informed by the vernacular conventions of their native language in this regard, this influence coexisted with syntactic patterns inherited from their earlier written Hebrew sources. This issue is one of many seen throughout the tales' grammar in which influence from Yiddish and earlier forms of Hebrew converges with the result that the permissible grammatical patterns are broader in Hasidic Hebrew than in any of these sources.

- ובבואם הרחק מאוד אל עיר גדולה שמה • המה ראו נפשות סובבות 'And when they went very far away, to a big city there, they saw spirits surrounding [them]' (Bodek 1865c: 20)

\subsubsection{OsV}

Although Hasidic Hebrew direct objects typically follow their associated verbs, in some cases they are fronted, as below. This technique generally serves to heighten the salience of the fronted form, though the force of the emphasis varies from case to case and in some contexts it appears to be stronger than others. The fronting of objects has precedent in Biblical Hebrew (van der Merwe, Naudé, and Kroeze 1999: 338; Williams 2007: 202), These sources may have exerted some influence on the Hasidic Hebrew construction. This is likely to have been compounded by Yiddish, in which the fronting of objects for emphasis is a common feature (Mark 1978: 387 ).

- מכתב חתום הבאתי לך מבעש״ט זל"ה I have brought you a sealed letter from the Ba'al Shem Tov of everlasting memory' (Ehrmann 1903: 4a)

- הסיפור הזה סיפר החסיד המפורסם ר׳ יחיאל ז"ל מווארשא 'The well-known Hasid R. Yechiel of Warsaw, of blessed memory, told this story' (Zak 1912: 34)

- את כל הבתים בווארשא מכר עוד בחייו 'He sold all of the houses in Warsaw already in his lifetime' (Teomim Fraenkel 1911b: 19) 
- וגם דמו נדרוש ממך 'And we will also demand his blood from you' (A. Walden 186o?: 29b)

- וגם אגרת נתן ביד השלוח 'And he also gave a letter to (lit: into the hand of) the messenger' (Seuss 1890: 5)

- והדלת סגר הגביר בעצמו 'And the rich man closed the door by himself' (Rodkinsohn 1865:13)

The fronting of indirect objects is not a typical feature of the tales, but is rarely attested:

- אבל רק לך אני מאמין 'But I believe only you' (Rodkinsohn 1864b: 6)

Prepositional phrases are very infrequently fronted in the same way in nonverbal sentences, e.g.:

- כי מן הל"ו צדיקים בטח אין החייט הזה 'Because this tailor was surely not one of the thirty-six [hidden] righteous ones' (Lieberson 1913: 65)

\subsubsection{SOV}

sov order is not a typical feature of Hasidic Hebrew, but a rare example is shown below. This very marginal practice seems to draw attention to the object in the same way as the more common fronting of the object to the beginning of the clause (as discussed above in 14.3.3), but it is so infrequent that it can only be regarded as an anomaly.

- הוא את נפשו הציל וברח משם 'He saved his life and fled from there' (Ehrmann 1903: 2a)

\subsubsection{Topicalization}

Topicalization via fronting is not an extremely common feature of the Hasidic Hebrew tales but is occasionally attested with nouns, noun phrases, and pronouns. The topicalized element is typically followed by a resumptive pronoun or possessive suffix. Topicalization (traditionally known as casus pendens) has precedent in Biblical Hebrew (van der Merwe, Naudé, and Kroeze 1999: 339; Gross 2013) and in Rabbinic Hebrew (Shivtiel 2013), as well as in later forms of the language, e.g. Paytanic Hebrew (Rand 2006: 243246).

- נשמת המת אין לו מנוחה 'As for] the spirit of the dead man, it has no rest' (Bromberg 1899: 25) 
- הלא עיר ברלין רחוקה היא מכאן 'Indeed, [as for] the city of Berlin, it is far from here' (Rodkinsohn 1865: 7)

- והרב ר' ליבער לא הי' לו בית מרחץ 'And [as for] Rabbi Lieber, he did not have a bathhouse' (Lieberson 1913: 45)

- עוד סיפר שאדם אחד נאחזה בו הקליפה הידועה בדמותה ר״ל 'He also said (lit: told) that [as for] a certain man, the evil force whose appearance is well-known attached itself to him, God protect us' (Landau 1892: 19)

- ויען ויאמר אני אין לי פנאי ללמוד 'And he answered and said, "[As for] me, I have no free time to study"' (Zak 1912:14)

- איש אחד יש לו דין ודברים עמכם 'There is a man who has an issue with you' (Teomim Fraenkel 1911b: 5)

- מחמת שחסידים אין להם שום שייכות עם גיהנם (Because as for Hasidim, they don’t have any connection with Hell' (Brill 1909: 27)

- אבל אתם אין לכם טעות 'But as for you, you haven't made a mistake' (Berger 1910c: 20$)$

- הלא אשתי שמה לאה 'Indeed as for my wife, her name is Leah' (Michelsohn 1910c: 69 )

- וגם אני היה בטחוני חזק 'And as for me, my faith was also strong' (Gemen 1914: 77)

Sometimes infinitive construct clauses are topicalized in the same way, as below. This practice is rarely attested in Mishnaic Hebrew (Sharvit 1998: 337), but it is doubtful that this marginal rabbinic phenomenon exerted any great influence on the Hasidic Hebrew authors. Yiddish is more likely to have been the direct inspiration as it has an identical parallel (Jacobs 2005: 260). The same construction has become a feature of Israeli Hebrew (Glinert 1989: 415).

- אד לשוב לבית חותנו לוויטעבסק לא רצה 'But as for returning to the house of his father in law in Vitebsk, he didn't want [that]' (Heilmann 1902: 23)

- אפשר שתתרפא אבל להבטיחך איני יכול 'It is possible that you will recover, but as for promising you, I can't [do that]' (Ehrmann 1903: 16a) 